\title{
Bartłomiej Wiejak
}

ORCID: 0000-0002-4595-7039

Uniwersytet Wrocławski

https://doi.org/10.19195/1733-5779.38.8

\section{Różnorodność jako wartość w employer brandingu na przykładzie komunikacji firm: Capgemini, IKEA, McDonald's i PZU}

Słowa kluczowe: różnorodność, zarządzanie różnorodnością, employer branding, wizerunek pracodawcy, analiza zawartości

Keywords: diversity, diversity management, employer branding, content analysis

Abstrakt: Jak prezentowana jest różnorodność w komunikacji employer brandingowej czterech polskich pracodawców? Do których jej wymiarów najczęściej nawiązują firmy? Analiza zawartości metodą jakościową objęła strony kariery, profile i ogłoszenia na Pracuj.pl, opisy profili w portalach społecznościowych Facebook, Instagram i LinkedIn, a obserwacje z niej zweryfikowano badaniem ilościowym postów w social mediach. Między 1 października a 31 grudnia 2020 roku firmy nawiązywały do różnorodności i prowadziły działania wspierające ją, choć w różnym stopniu - Capgemini odnosiło się do 19 wymiarów, IKEA - 17, McDonald's - 11, a PZU - 9. Różnorodność to pożądana wartość dla trzech firm: Capgemini — głównie w kontekście korzyści biznesowych, IKEA — tworzenia rozwiązań dla klientów i swobody pracowników, McDonald's poszerzania horyzontów (choć bywa wyzwaniem). W komunikacji bieżącej Capgemini i PZU najczęściej poruszały kwestie doświadczenia zawodowego i hobby, IKEA — wieku, płci, doświadczenia i stylu życia, McDonald's — płci, wieku, niepełnosprawności.

\section{Diversity as a value in employer branding - case study of companies' communication: Capgemini, IKEA, McDonald's, and PZU}

\begin{abstract}
How is diversity presented in the employer branding communication of four Polish employers? Which of its dimensions do the companies most frequently refer to? The qualitative content analysis included career pages, profiles and job postings on Pracuj.pl, and Facebook, Instagram, or LinkedIn profile descriptions. Observations were verified by quantitative analysis of social media posts. Between 1.10 and 31.12.2020 companies referred to diversity and conducted activities supporting it, but to different degrees - Capgemini referring to 19 dimensions, IKEA 17, McDonald's - 11, PZU - 9. Diversity is a desired value for three companies: Capgemini mainly in terms of business benefits, IKEA - creating solutions for customers and employee
\end{abstract}


satisfaction, McDonald's — broadening horizons (although it can be challenging). In current communication. Capgemini and PZU most often mentioned work experience and hobby, IKEA — age, gender, work experience, lifestyle, McDonald's — gender, age, disability.

Praca w zespołach wielokulturowych (nie tylko narodowo-etnicznie), z osobami z różnych grup społecznych, to już codzienność. Jak wskazuje Elwira Gross-Gołacka, jest to „różnorodność, którą ludzkość musi zarządzać”. Owo zarządzanie powinno być oparte na kompleksowym podejściu, uwzględniającym działania komunikacyjne ${ }^{2}$. Można założyć, że taka komunikacja będzie elementem employer brandingu, czyli — jak tłumaczy to pojęcie Marek Kozłowski — „budowania wizerunku pracodawcy” w oczach „obecnych oraz potencjalnych pracowników”3.

Podstawowe kategorie różnorodności zostały zdefiniowane przez Marylin Loden i Judy B. Rosener ${ }^{4}$, które określiły jej pierwotne i wtórne wymiary, określające różnice i podobieństwa między ludźmi. Pierwotne wymiary to cechy, z którymi ludzie się rodzą lub które mają duży wpływ na wczesną socjalizację, postrzeganie świata, funkcjonowanie przez całe życie. Wtórne wymiary to cechy niewrodzone, które mogą mieć mniejsze znaczenie w życiu człowieka i mogą się zmieniać.

Tabela 1. Wymiary różnorodności według M. Loden i J.B. Rosener

\begin{tabular}{|l|l|}
\hline \multicolumn{1}{|c|}{ Wymiary pierwotne } & \multicolumn{1}{|c|}{ Wymiary wtórne } \\
\hline $\begin{array}{l}\text { wiek, pochodzenie } \\
\text { etniczne, płeć, niepeł- } \\
\text { nosprawność, rasa, } \\
\text { orientacja seksualna }\end{array}$ & $\begin{array}{l}\text { między innymi: język, religia, narodowość, wykształcenie, stan cy- } \\
\text { majątkowy, miejsce pracy, doświadczenie zawodo zame, system wartości, } \\
\text { styl życia, hobby, kultura, wygląd fizyczny, poglądy polityczne }\end{array}$ \\
\hline
\end{tabular}

Źródło: M. Loden, J.B. Rosener, Workforce America! Managing Employee Diversity as a Vital Resource, Illinois 1991, cyt. za: E. Gross-Gołacka, Zarządzanie różnorodnością. W kierunku zróżnicowanych zasobów ludzkich w organizacjach, Warszawa 2018, s. 38-41.

W jaki sposób w komunikacji employer brandingowej w Polsce prezentowana jest różnorodność i do których wymiarów najczęściej nawiązują firmy? Próbę odpowiedzi na te pytania stanowi badanie kanałów komunikacji budującej wizerunek pracodawcy czterech firm: Capgemini, IKEA, McDonald's i PZU. Badanie składa się z dwóch elementów: analizy metodą jakościową zawartości treści „statycznych" (strona/zakładka kariery, profil w portalu Pracuj.pl, opis firmy na pro-

${ }^{1}$ E. Gross-Gołacka, Zarządzanie różnorodnościa. W kierunku zróżnicowanych zasobów ludzkich $w$ organizacjach, Warszawa 2018, s. 26.

2 Ibidem, s. 50-51.

3 M. Kozłowski, Employer branding. Budowanie wizerunku pracodawcy krok po kroku, Warszawa 2012, s. 13.

${ }^{4}$ M. Loden, J.B. Rosener, Workforce America! Managing Employee Diversity as a Vital Resource, Illinois 1991, cyt. za: E. Gross-Gołacka, Zarządzanie różnorodnością. W kierunku zróżnicowanych zasobów ludzkich w organizacjach, Warszawa 2018, s. 38-41. 
filach w social mediach — aktualne na 31 grudnia 2020 roku, przy założeniu, że informują o stałych wartościach firmy). Obserwacje z tej analizy zostały zweryfikowane analizą metodą ilościową zawartości treści ,bieżących” (postów w social mediach w okresie 1 października do 31 grudnia 2020 roku).

Wybrane firmy są sygnatariuszami Karty Różnorodności ${ }^{5}$, ale jednocześnie zostały uznane w raporcie HRM Institute ${ }^{6}$ za liderów employer brandingu w Polsce w 2020 roku. Analizowane kanały komunikacji również wybrano na podstawie wskazań raportu, jako pięć najpopularniejszych kanałów (Pracuj.pl to największy pod względem liczby ogłoszeń rekrutacyjnych portal ogłoszeniowy/pracy w Pol$\left.\mathrm{sce}^{7}\right)$. W analizie uwzględniono 23 wymiary różnorodności, wymienione w tabeli 1., wybrane ze względu na przewidywaną istotność dla badania.

Klucz kategoryzacyjny badania uwzględniał:

1. wykorzystanie kanałów komunikacji employer brandingowej (czy firma korzysta z danego kanału w Polsce i czy ma on wersje językowe inne niż polska),

2. odniesienie do różnorodności jako wartości (czy firma opisuje różnorodność jako pozytywnie wpływającą na organizację i jakie cechy są jej przypisywane),

3. nawiązanie do wymiarów różnorodności w warstwie tekstowej (ze wskazaniem kontekstu; przy analizie należy zwrócić uwagę, czy język zachowuje neutralność płciową),

4. nawiązanie do wymiarów różnorodności w warstwie graficznej (ze wskazaniem kontekstu),

5. nawiązanie do wymiarów różnorodności w materiałach wideo (ze wskazaniem kontekstu),

6. przedstawienie działań/rozwiązań wspierających różnorodność.

Wyniki analizy metodą jakościową zweryfikowano badaniem ilościowym, by wykazać, które wymiary różnorodności są przywoływane najczęściej w bieżącej komunikacji w social mediach. Dla każdej firmy opracowano kategorie odpowiadające wymiarom, do których nawiązywała w kanałach analizowanych jakościowo, w podziale na medium społecznościowe i typ treści (tekst, grafika, wideo). Dodatkową kategorię stanowiły ogólnie posty prezentujące różnorodność jako pożądaną wartość.

\section{CAPGEMINI}

Spośród uwzględnionych kanałów Capgemini korzysta z zakładki kariery na

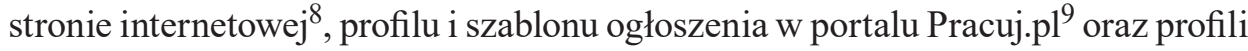

\footnotetext{
5 http://odpowiedzialnybiznes.pl/karta-roznorodnosci/sygnatariusze-karty/(dostęp: 31.12.2020).

${ }^{6}$ HRM Institute, Raport: Employer branding w Polsce 2020, Kraków 2020.

7 https://www.employear.com/pl/blog/wyszukiwarki-ofert-pracy.html (dostęp: 31.12.2020).

8 https://www.capgemini.com/pl-pl/kariera/ (dostęp: 31.12.2020).

9 https://pracodawcy.pracuj.pl/capgemini-polska-sp-z-o-o,19 (dostęp: 31.12.2020).
} 
na Facebooku ${ }^{10}$ i Instagramie ${ }^{11}$. Kanały prowadzone są w języku polskim (szablon ogłoszenia występuje także w wersji angielskiej). Firma ma tylko ogólnoświatowy profil LinkedIn, z opisem firmy w języku angielskim (w różnych językach publikowane są bieżące posty — w tym po polsku, gdy dotyczą działań w Polsce).

Capgemini wprost określa różnorodność jako pożądaną wartość. Na stronie kariery i jej podstronach (w tym jednej poświęconej różnorodności ${ }^{12}$ ) firma deklaruje, że „różnorodność jest głęboko zakorzeniona w [jej] kulturze organizacyjnej” $i$ to $z$ różnorodności czerpie ona swoją siłę ${ }^{13}$. W firmie różnorodność to „środowisko pracy”14 — „różne osoby spotykają się w jednym zespole, wnosząc kreatywne rozwiązania, przynoszące nowe rezultaty” ${ }^{15}$, a „praca z utalentowanymi osobami z różnych środowisk i o zróżnicowanym doświadczeniu jest zaletą i szansą na stały rozwój firmy”16. Różnorodność stanowi „potencjał”, inspiruje, wpływa na lepszą komunikację, otwiera na nowe perspektywy i punkty widzenia, a „pielęgnowanie tych różnic i dążenie do poszerzania perspektyw" jest cenne, ponieważ „wpływa na efektywność pracy zespołowej, co stanowi ogromną wartość dla całej organizacji”" ${ }^{\prime 17}$. Na profilu LinkedIn firma wskazuje, w sekcji „Diversity \& Inclusion”, że koncentruje się na rekrutowaniu i utrzymywaniu „utalentowanej, różnorodnej grupy niezwykłych osób", oraz podkreśla, że wzajemny szacunek wobec indywidualności to dodatkowa wartość dla biznesu.

Wątek różnorodności często pojawia się w tekstach Capgemini. Już na stronie głównej zakładki kariery firma pokazuje, że szeroko postrzega różnorodność:

[J]esteśmy obecni w 50 krajach, a pracownicy mówią w ponad 100 różnych językach. Dla nas różnorodność to coś więcej, bo obejmuje wiele innych wymiarów, takich jak płeć, pochodzenie etniczne, wiek i styl życia, także poszanowanie niepełnosprawności, indywidualności każdego $\mathrm{z}$ nas. Wspieramy [...] zainteresowania oraz postawy społeczne pracowników.

Poszczególne wymiary różnorodności pojawiają się w opisach kampanii employer brandingowej \#AmongOthers (lub \#MiędzyInnymi), która opiera się na odpowiedziach pracowników na „odważne pytania”, między innymi o role społeczne, role zawodowe, stereotypy, różnice kulturowe. W ten sposób firma przedstawia się jako różnorodna dzięki cechom pracowników:

Capgemini tworzą osoby z pokolenia X i Y, zarówno Polacy, jak też obcokrajowcy z różnych zakątków świata, ludzie o różnorakiej aparycji, czasem o różnych stopniach niepełnosprawności.

10 https://www.facebook.com/CapgeminiPl/ (dostęp: 31.12.2020).

$11 \mathrm{https}: / /$ www.instagram.com/capgeminipl/ (dostęp: 31.12.2020).

12 https://www.capgemini.com/pl-pl/roznorodnosc/ (dostęp: 31.12.2020).

$13 \mathrm{https} / / /$ www.capgemini.com/pl-pl/kariera/ (dostęp: 31.12.2020).

$14 \mathrm{https}: / /$ www.capgemini.com/pl-pl/kariera/pracuj-z-nami/ (dostęp: 31.12.2020).

15 https://www.capgemini.com/pl-pl/kariera/life-at-capgemini/ (dostęp: 31.12.2020).

$16 \mathrm{https}: / /$ www.capgemini.com/pl-pl/roznorodnosc/ (dostęp: 31.12.2020).

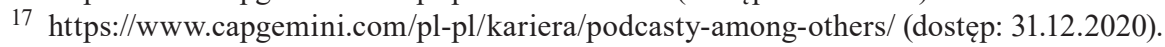


Każdy reprezentuje odmienne doświadczenia, światopoglądy i pasje, jak również inne dziedziny zawodowe ${ }^{18}$.

Różnorodności pracowników dowodzi też podstrona „Employee stories”19, gdzie 30 osób dzieli się swoją perspektywą. Odnoszą się one między innymi do statusu rodzicielskiego, zainteresowań, wyglądu zewnętrznego, języka, kultury, pochodzenia etnicznego, a także motywacji lub chęci angażowania się społecznie (co można rozumieć jako kwestie systemu wartości).

Firma nawiązuje do różnorodności w anglojęzycznym szablonie ogłoszenia rekrutacyjnego i w opisie w portalu Pracuj.pl (,,multicultural project teams" ${ }^{20}$, „wielokulturowa organizacja" ${ }^{21}$ ). W innym charakterze nawiązanie pojawia się na profilu na Facebooku — firma wskazuje, że komentarze rasistowskie, homofobiczne, transfobiczne, seksistowskie, antyreligijne itp. będą usuwane.

W tekstach na stronie kariery i w polskojęzycznym szablonie ogłoszenia stosowane są bezpośrednie zwroty, które zwykle mają neutralną płciowo formę drugiej osoby liczby pojedynczej trybu rozkazującego. Dodatkowo na neutralność wpływa na przykład brak czasowników w czasie przeszłym (lub stosowanie alternatywnych końcówek — „ukończyłeś/aś”) lub przymiotników (nie licząc wyjątków, jak ,jesteś [...] dyspozycyjny"22).

Elementy graficzne w analizowanych kanałach firmy to głównie zdjęcia pracowników. Często przedstawiają co najmniej dwie osoby, nierzadko grupy, a gdy zdjęciem jest indywidualny portret, to zwykle nie jest ono jedyne na stronie, dlatego osoba na zdjęciu również jest postrzegana jako część grupy pracowników (ponadto grafiki nagłówkowe $\mathrm{z}$ indywidualnymi portretami rotują — odwiedzający stronę mogą zobaczyć w tym samym miejscu różnych pracowników). Na zdjęciach są przedstawione osoby w różnym wieku, o różnym pochodzeniu etnicznym $\mathrm{i}$ wyglądzie, kobiety i mężczyźni. Fotografie to zdjęcia z korporacyjnych sesji oraz wydarzeń, takich jak zawody sportowe, przedstawienia teatralne. Na jednym ze zdjęć widoczny jest symbol religijny (bindi), nie zaobserwowano jednak symboli innych wymiarów różnorodności, jak na przykład narodowość, język, system wartości.

Firma nawiązuje do wymiarów różnorodności także w filmach. Na profilu LinkedIn zamieszczono wideo ${ }^{23}$, w którym o pracy opowiadają trzy kobiety i trzej mężczyźni, o różnych kolorach skóry, w różnym wieku, a ich wypowiedziom towarzyszą zdjęcia innych pracowników, zróżnicowanych w tych samych wymia-

18 https://www.capgemini.com/pl-pl/kariera/pracuj-z-nami/poznaj-nas/among-others/ (dostęp: 31.12.2020).

19 https://www.capgemini.com/pl-pl/employee-stories/, (dostęp: 31.12.2020).

$20 \mathrm{https} / /$ www.pracuj.pl/praca/application-administrator-warszawa,oferta,1000649177 (dostęp: 31.12.2020).

21 https://pracodawcy.pracuj.pl/capgemini-polska-sp-z-o-o,19 (dostęp: 31.12.2020).

22 https://www.capgemini.com/pl-pl/kariera/studenci-i-absolwenci/ (dostęp: 31.12.2020).

$23 \mathrm{https}: / /$ youtu.be/CGkJiqwSRg (dostęp: 31.12.2020). 
rach. Inne wideo ${ }^{24}$ na profilu w portalu Pracuj.pl i na stronach kariery prezentuje pracowników w Polsce w statystycznym ujęciu: liczba kobiet i mężczyzn, wiek, miejsce pracy, język, pełnione funkcje, hobby, a nawet najczęstsze imiona. Bardziej ogólnie różnorodność jest tematem filmów w kampanii \#AmongOthers, które dotyczą różnic między pokoleniami, między rodzicami a osobami bez dzieci, między Polakami a obcokrajowcami, między informatykami a humanistami oraz między menadżerami a osobami na stanowiskach niekierowniczych. Na podstronie dotyczącej programu „Women@Capgemini”25 znajduje się film o perspektywie kobiet i jej znaczeniu w biznesie, a na podstronie o różnorodności — film o wsparciu dla pracowników z niepełnosprawnością.

W badanym okresie głównym działaniem firmy na rzecz różnorodności była wspomniana kampania \#AmongOthers, o walorze edukacyjnym dla osób wewnątrz i spoza organizacji. Warto podkreślić obecność specjalnych podstron na stronie kariery, dotyczących różnorodności, kobiet w biznesie i pracujących rodziców. Kilka inicjatyw jest wskazanych na podstronie poświęconej różnorodności:

1. „Win with Capgemini” - program wspierający zatrudnianie osób z niepełnosprawnościami (na przykład przez dostosowanie stanowiska pracy, szkolenia dla pozostałych pracowników);

2. „Projekt Teatr” — coroczny spektakl pracowniczy, z którego zysk wspiera edukację osób z niepełnosprawnościami;

3. zainicjowanie powstania deklaracji „Biznes bliżej niepełnosprawności” oraz międzysektorowej grupy Come CloSeR to disability task force;

4. „Program Business Parent”;

5. wsparcie edukacji kobiet w IT, program rozwojowy „Outstanding Women in Leadership”, międzynarodowy program „Women@Capgemini”.

Na stronach kariery znajdują się informacje o konkretnych rozwiązaniach, które uwzględniają różnorodność pracowników, jak: technologie wspierające osoby z niepełnosprawnościami, niestosowanie dress code’u (różnorodność wyglądu fizycznego), programy rozwojowe dostosowane do stanowiska i etapu kariery, ścieżki kariery dla studentów/absolwentów oraz ekspertów/profesjonalistów.

W ogłoszeniu rekrutacyjnym ${ }^{26}$ firma podkreśla dodatkowo elastyczny czas pracy i różne wymiary etatu (umożliwiające dostosowanie pracy do życia prywatnego).

Badanie jakościowe wykazało, że Capgemini w komunikacji employer brandingowej nawiązuje do 19 uwzględnionych wymiarów różnorodności. Na tej pod-

24 https://youtu.be/K8v_UJ7CH8c (dostęp: 31.12.2020).

25 https://www.capgemini.com/pl-pl/kariera/life-at-capgemini/womencapgemini/ (dostęp: 31.12.2020).

${ }^{26} \mathrm{https} / / /$ www.pracuj.pl/praca/senior-ios-developer-wroclaw,oferta,1000647108 (dostęp: 31.12.2020). 
stawie zostały opracowane kategorie do analizy metodą ilościową, której wyniki prezentuje tabela 2 .

Tabela 2. Wymiary różnorodności w komunikacji firmy Capgemini w social mediach (1.1031.12.2020)

\begin{tabular}{|c|c|c|c|c|c|c|c|c|c|}
\hline Capgemini & \multicolumn{3}{|c|}{$\begin{array}{c}\text { Facebook } \\
\text { liczba postów: } 86\end{array}$} & \multicolumn{3}{|c|}{$\begin{array}{c}\text { Instagram } \\
\text { liczba postów: } 37\end{array}$} & \multicolumn{3}{|c|}{$\begin{array}{c}\text { LinkedIn } \\
\text { liczba postów: } 89\end{array}$} \\
\hline $\begin{array}{l}\text { typ treści } \\
\text { wymiar różnorodności } \\
{[\%]}\end{array}$ & $\begin{array}{c}\text { tekst } \\
92\end{array}$ & $\begin{array}{c}\text { grafika } \\
80\end{array}$ & $\begin{array}{c}\text { wideo } \\
16\end{array}$ & $\begin{array}{l}\text { tekst } \\
97\end{array}$ & $\begin{array}{c}\text { grafika } \\
84\end{array}$ & $\begin{array}{c}\text { wideo } \\
16\end{array}$ & $\begin{array}{l}\text { tekst } \\
100\end{array}$ & $\begin{array}{c}\text { grafika } \\
85\end{array}$ & $\begin{array}{c}\text { wideo } \\
9\end{array}$ \\
\hline wiek $[\%]$ & 2 & 2 & 1 & - & - & 3 & 6 & 3 & - \\
\hline pochodzenie etniczne [\%] & 2 & 2 & 1 & - & - & 3 & 9 & 7 & - \\
\hline płeć [\%] & 8 & 5 & 5 & - & 3 & 5 & 11 & 7 & 3 \\
\hline niepełnosprawność [\%] & - & - & - & - & - & - & - & - & - \\
\hline $\operatorname{rasa}[\%]$ & - & - & 1 & - & - & 3 & - & 1 & - \\
\hline orientacja seksualna & - & - & - & - & - & - & - & - & - \\
\hline język [\%] & 1 & 12 & - & 3 & 3 & 3 & 2 & - & - \\
\hline religia $[\%]$ & - & - & - & - & - & - & - & - & - \\
\hline narodowość [\%] & - & - & - & - & 3 & - & 1 & - & - \\
\hline wykształcenie [\%] & 1 & 1 & - & - & - & - & - & - & - \\
\hline status rodzicielski [\%] & 1 & - & 1 & 3 & - & 3 & 1 & - & 1 \\
\hline miejsce pracy [\%] & - & - & - & 3 & - & - & 3 & 1 & - \\
\hline $\begin{array}{l}\text { doświadczenie zawodo- } \\
\text { we [\%] }\end{array}$ & 26 & 3 & 1 & 3 & 3 & 3 & 33 & 3 & 2 \\
\hline system wartości [\%] & - & 12 & 1 & 16 & 16 & - & 3 & 9 & 1 \\
\hline styl życia [\%] & 5 & - & 3 & 11 & - & 8 & 6 & - & 3 \\
\hline hobby [\%] & 9 & 1 & 2 & 22 & 8 & 5 & 13 & 1 & 2 \\
\hline kultura $[\%]$ & - & - & - & 3 & 3 & - & 1 & - & - \\
\hline wygląd fizyczny [\%] & - & 1 & 3 & - & 3 & 3 & - & 1 & - \\
\hline poglądy polityczne [\%] & 1 & - & - & - & - & - & 2 & - & - \\
\hline $\begin{array}{l}\text { różnorodność jako war- } \\
\text { tość [\%] }\end{array}$ & & 6 & & & 8 & & & 7 & \\
\hline
\end{tabular}

Wymiary, do których firma nawiązała we wszystkich badanych kanałach i typach treści, to doświadczenie zawodowe i hobby. Bez rozróżniania typu treści we wszystkich analizowanych kanałach firma nawiązała do różnorodności pod względem wieku, pochodzenia etnicznego, płci, rasy, języka, statusu rodzicielskiego, doświadczenia zawodowego, systemu wartości, stylu życia, hobby, kultury i wyglądu fizycznego. W bieżącej komunikacji nie pojawiły się nawiązania do niepeł- 
nosprawności, orientacji seksualnej i religii. W każdym kanale pojawiły się posty prezentujące różnorodność jako wartość.

\section{IKEA}

Spośród uwzględnionych kanałów IKEA korzysta z zakładki kariery na stronie internetowej ${ }^{27}$, profilu i szablonu ogłoszenia w portalu Pracuj.pl ${ }^{28}$ oraz profili na Facebooku ${ }^{29}$ i Instagramie ${ }^{30}$. Kanały prowadzone są w języku polskim (anglojęzyczne są jedynie ogłoszenia na niektóre stanowiska w centrali). Firma nie prowadzi profilu LinkedIn skierowanego tylko do polskich odbiorców — istnieje globalny, anglojęzyczny profil ${ }^{31}$.

Na profilu Pracuj.pl, w sekcji „Rozwój i kultura”, IKEA stwierdza, że różnorodność pracowników to fakt, i deklaruje, że akceptujące otoczenie to część kultury organizacyjnej: „Jesteśmy różni i dbamy o to, aby w IKEA każdy czuł się dobrze”. Różnorodność to wręcz ,metawartość":

To, co w największym stopniu przybliża wartości IKEA pracownikom, to my sami. Ponieważ w naszym procesie rekrutacyjnym najważniejsze są wartości IKEA, to — bez względu, kogo i z jakiego kraju na świecie spotykamy — od razu znajdujemy wspólny język.

W zakładce kariery znajduje się podstrona poświęcona różnorodności ${ }^{32}$. Firma wyraża tam pozytywne podejście do różnorodności oraz chęć tworzenia otwartego środowiska pracy: „Cenimy różnorodność naszych pracowników”, „Wspieramy otwartą kulturę pracy, gdzie każdy czuje swoją przynależność, jest mile widziany, szanowany, akceptowany i doceniany za swoją wyjątkowość". Jednocześnie IKEA wskazuje, ,jak wiele dobrego wnosi to do naszej organizacji” — przypisując różnorodności wpływ na rozwój, kreatywność, inspirację i zrozumienie klientów. Na stronie zaprezentowane są wypowiedzi pracowników, którzy dzielą się swoim rozumieniem różnorodności: „otwartość na to, co różni mnie od innych, i pełny szacunek do tych różnic”, „tolerancja”, ,,szacunek i równość dla wszystkich”.

W tekstach na profilu w portalu Pracuj.pl IKEA nawiązuje do różnorodności w wymiarze doświadczenia zawodowego, hobby, poglądów politycznych, narodowości: „Ważniejsze dla nas jest to, kim jesteś, a nie jakie masz doświadczenie zawodowe”, „,bez względu, kogo i z jakiego kraju na świecie spotykamy — od razu znajdujemy wspólny język” oraz „Mamy odmienne zainteresowania, charaktery oraz poglądy, a dzięki niezwykłej, pełnej otwartości atmosferze możemy być po

$27 \mathrm{https}: / /$ www.ikea.com/pl/pl/this-is-ikea/work-with-us/ (dostęp: 31.12.2020).

28 https://pracodawcy.pracuj.pl/ikea-retail-sp-z-o-o,14871 (dostęp: 31.12.2020).

29 https://www.facebook.com/pracawIKEA (dostęp: 31.12.2020).

$30 \mathrm{https} / / / \mathrm{www}$. instagram.com/pracawikea/?hl=pl (dostęp: 31.12 .2020$)$.

$31 \mathrm{https} / / / \mathrm{www}$. linkedin.com/company/ikea/about/ (dostęp: 31.12.2020).

$32 \mathrm{https} / / / \mathrm{www} . i k e a . c o m / \mathrm{pl} / \mathrm{pl} /$ this-is-ikea/work-with-us/roznorodnosc-i-wlaczanie-pubc81a0850 (dostęp: 31.12.2020). 
prostu sobą”. W ostatnim z przytoczonych cytatów mowa jest o „charakterach”, które w tym kontekście można interpretować jako nawiązanie do stylu życia. Jednoznacznie jest mowa o wymiarze miejsca pracy, wskazuje się na różne lokalizacje sklepów, biur i punktów odbioru.

Nawiązania do wymiarów różnorodności znaleźć można w tekstach na stronie kariery (podstronie dotyczącej różnorodności). Firma deklaruje, że umożliwia „rozwój w sposób, który najbardziej ci odpowiada” — co można rozumieć jako nawiązanie do różnorodności systemów wartości. Jednoznacznie mówi się o pochodzeniu etnicznym (,Jesteśmy z różnych zakątków świata, ale nikt nie jest obcy”), płci i doświadczeniu zawodowym (,Wszyscy — niezależnie od płci mają szansę na sukcesję i rozwój w IKEA, na każdym etapie kariery"), a trzy kolejne wymiary wskazane są w cytacie pracownicy:

Najbardziej w IKEA uwielbiam bycie sobą, ze względu na to, że niezależnie od tego, czy jest się okolczykowanym, czy [...] wytatuowanym, czy jest się takich poglądów, a nie innych, takiej czy innej orientacji - można być po prostu sobą.

Kolejne wymiary pojawiają się na podstronie „Nasi pracownicy”: „Pochodzimy z wielu miast, mamy odmienne zainteresowania, poglądy i charaktery" oraz „mimo różnic wieku każdy czuje się tu niesamowicie swobodnie”33. FAQ na temat zasad rekrutacji zapewnia, że „każdy, niezależnie od narodowości, jest mile widziany" 34 .

Język w analizowanych kanałach komunikacji IKEA jest ogólnie neutralny płciowo (na przykład dzięki czasownikom w pierwszej lub trzeciej osobie liczby mnogiej w czasie teraźniejszym), jednakże zdarzają się formy tylko męskie — jak wskazane „każdy” lub ,zainteresowania i pasje zaprowadzą Cię do zupełnie innego działu IKEA niż ten, w którym zaczynałeś"35.

Grafiki w kanałach komunikacji IKEA przedstawiają pracowników i pracownice, głównie w sklepach. W większości to osoby młodsze niż 30-40 lat, jednak pojawiają się też osoby powyżej czterdziestego roku życia. Zauważalna jest różnorodność wyglądu, na przykład przez kolczyki, tatuaże i kolorowe fryzury. $\mathrm{Na}$ zdjęciach widoczne są osoby o różnych kolorach skóry, choć znaczną większość stanowią osoby białe. Zazwyczaj zachowana jest równa reprezentacja płci, szczególnie gdy obok siebie zamieszczonych jest kilka zdjęć (grupowych lub portretów). Nie dotyczy to profilu LinkedIn (nierówność na „,korzyść” kobiet).

Materiały wideo przedstawiają pracowników znanych ze zdjęć. Film nagłówkowy na profilu na Facebooku prezentuje trzy pracownice i dwóch pracowników, o zróżnicowanym wyglądzie, lecz w podobnie młodym wieku (oprócz jednej oso-

33 https://www.ikea.com/pl/pl/this-is-ikea/work-with-us/nasi-pracownicy-sylwia-pubec378541 (dostęp: 31.12.2020).

34 https://www.ikea.com/pl/pl/this-is-ikea/work-with-us/rekrutacja-potwojemu-pub71f4lbf1 (dostęp: 31.12.2020).

35 https://www.facebook.com/pracawIKEA (dostęp: 31.12.2020). 
by). Reprezentują różne działy sklepów, a podział na te obszary jest podkreślony w filmach zamieszczonych na stronie kariery (oraz w ogłoszeniach rekrutacyjnych do danego działu). Pracownicy mówią w nich o charakterze pracy, a także o tym, co najbardziej w niej cenią (nawiązując do różnorodności miejsca pracy oraz systemu wartości). Jedna z pracownic ${ }^{36}$ docenia dopasowanie pracy do jej potrzeb jako studentki oraz możliwość bycia sobą (wymienia wygląd fizyczny kolczyki, które sama posiada, oraz tatuaże, a także poglądy i orientację seksualną). Inne pracownice stwierdzają, że w IKEA „każdy ma swoją drogę i każda jest niepowtarzalna" 37 i że możliwy jest wybór, „w jakim kierunku chce się rozwijać" ${ }^{38}$. Inny pracownik mówi o pracy z osobami w różnym wieku ${ }^{39}$, a następny sam jest „dowodem” różnorodności — to mężczyzna starszy od bohaterów pozostałych nagrań, z wytatuowanymi przedramionami i śladem po tunelach w uszach, pracujący w IKEA od 18 lat ${ }^{40}$.

Działania firmy, które wspierają różnorodność, to między innymi benefity ${ }^{41}$, jak ubezpieczenie obejmujące też dzieci i wnuki lub dofinansowanie posiłków w pracy (które mogą być także wegetariańskie) — co jest odpowiedzią na różnorodność statusu rodzicielskiego, stanu majątkowego i stylu życia. W sekcji „Różnorodność i włączanie" firma wymienia inne inicjatywy, a jednocześnie zwiększa świadomość czytelników: wspomina o wprowadzeniu dodatkowego, pełnopłatnego urlopu ojcowskiego, prowadzeniu badań płac celem eliminowania różnic w wynagrodzeniach kobiet i mężczyzn na stanowiskach o jednakowej wartości, deklaruje też, że zapewnia równe szanse rozwoju niezależnie od płci i utrzymuje równą liczbę kobiet i mężczyzn na wszystkich poziomach stanowisk.

IKEA umożliwia różnorodny rozwój zawodowy poprzez programy transferów między działami, sklepami, a nawet krajami, a przede wszystkim przez rozwiązanie „fleksy” ${ }^{\$ 2}$, polegające na dzieleniu etatu między dwa działy. Pracownicy mogą też, niezależnie od zajmowanego stanowiska, brać udział w interdyscyplinarnych projektach wewnętrznych. W firmie jest możliwa praca w różnych wymiarach etatu i w elastycznych godzinach, co prezentowane jest szczególnie jako odpowiedź

36 https://youtu.be/-KcvfVtD6dw (dostęp: 31.12.2020).

$37 \mathrm{https}: / /$ youtu.be/qvqUsBX0 ik (dostęp: 31.12.2020).

$38 \mathrm{https}: / /$ youtu.be/UCEfD7svlec (dostęp: 31.12.2020).

39 https://youtu.be/Efx9TmmQkiE (dostęp: 31.12.2020).

$40 \mathrm{https} / / /$ youtu.be/KqJXKDmqLFE (dostęp: 31.12.2020).

$41 \mathrm{https} / / / \mathrm{www} . i k e a . c o m / \mathrm{pl} / \mathrm{pl} /$ this-is-ikea/work-with-us/benefity-pub72de67d1 (dostęp: 31.12.2020).

42 https://pracodawcy.pracuj.pl/ikea-retail-sp-z-o-o,14871/strona/rozwoj-i-kultura (dostęp: 31.12.2020). 
na potrzeby osób na studiach ${ }^{43}$. W czasie procesu rekrutacyjnego ${ }^{44}$ kandydat nie musi przesyłać klasycznego CV — może posłużyć się formą prezentacji, filmu lub listu, choć zależy to od stanowiska. W przypadku rekrutacji w Warszawie firma zaprasza kandydatów do Twojego Studia Pracy, dokąd mogą przyjść z dziećmi, które na czas rozmowy zostaną objęte opieką ${ }^{45}$.

Badanie jakościowe wykazało, że IKEA w komunikacji employer brandingowej nawiązuje do 17 uwzględnionych wymiarów różnorodności. Na tej podstawie zostały opracowane kategorie do analizy metodą ilościową, której wyniki prezentuje tabela 3 .

Tabela 3. Wymiary różnorodności w komunikacji firmy IKEA w social mediach (1.10-31.12.2020)

\begin{tabular}{|c|c|c|c|c|c|c|c|c|c|}
\hline IKEA & \multicolumn{3}{|c|}{$\begin{array}{c}\text { Facebook } \\
\text { liczba postów: } 38\end{array}$} & \multicolumn{3}{|c|}{$\begin{array}{c}\text { Instagram } \\
\text { liczba postów: } 26\end{array}$} & \multicolumn{3}{|c|}{$\begin{array}{l}\text { LinkedIn } \\
\text { (0 postów } \\
\text { po polsku) }\end{array}$} \\
\hline $\begin{array}{l}\text { typ treści } \\
\text { wymiar różnorodności [\%] }\end{array}$ & \begin{tabular}{|c|} 
tekst \\
100
\end{tabular} & $\begin{array}{c}\text { grafika } \\
84\end{array}$ & $\begin{array}{c}\text { wideo } \\
13\end{array}$ & $\begin{array}{c}\text { tekst } \\
100\end{array}$ & $\begin{array}{c}\text { grafika } \\
100\end{array}$ & wideo & tekst & $\begin{array}{c}\text { grafika } \\
-\end{array}$ & wideo \\
\hline wiek [\%] & 3 & - & 3 & 4 & 4 & - & - & - & - \\
\hline pochodzenie etniczne [\%] & - & - & - & - & - & - & - & - & - \\
\hline płeć [\%] & 5 & 3 & 3 & 15 & 8 & - & - & - & - \\
\hline $\operatorname{rasa}[\%]$ & - & - & - & - & - & - & - & - & - \\
\hline orientacja seksualna [\%] & - & - & - & - & 4 & - & - & - & - \\
\hline narodowość [\%] & - & - & - & - & - & - & - & - & - \\
\hline wykształcenie [\%] & - & - & - & - & - & - & - & - & - \\
\hline status rodzicielski [\%] & - & - & - & - & - & - & - & - & - \\
\hline miejsce zamieszkania [\%] & - & - & - & 4 & 4 & - & - & - & - \\
\hline stan majątkowy [\%] & - & - & - & - & - & - & - & - & - \\
\hline miejsce pracy [\%] & - & - & - & - & - & - & - & - & - \\
\hline $\begin{array}{l}\text { doświadczenie zawodowe } \\
{[\%]}\end{array}$ & 5 & 3 & - & 12 & - & - & - & - & - \\
\hline system wartości [\%] & - & - & - & - & - & - & - & - & - \\
\hline styl życia [\%] & 8 & - & 3 & 19 & - & - & - & - & - \\
\hline hobby [\%] & - & - & - & - & - & - & - & - & - \\
\hline wygląd fizyczny [\%] & - & - & - & - & 4 & - & - & - & - \\
\hline
\end{tabular}

43 https://www.ikea.com/pl/pl/this-is-ikea/work-with-us/nasi-pracownicy-sylwia-pubec378541 (dostęp: 31.12.2020).

${ }^{44} \mathrm{https} / / / w w w . i k e a . c o m / p l / p l / t h i s-i s-i k e a / w o r k-w i t h-u s / r e k r u t a c j a-p o t w o j e m u-p u b 71 f 41 b f 1$ (dostęp: 31.12.2020).

45 https://youtu.be/pgCMKUIWmIE (dostęp: 31.12.2020). 


\begin{tabular}{|c|c|c|c|c|c|c|c|c|c|}
\hline IKEA & \multicolumn{3}{|c|}{$\begin{array}{c}\text { Facebook } \\
\text { liczba postów: } 38\end{array}$} & \multicolumn{3}{|c|}{$\begin{array}{c}\text { Instagram } \\
\text { liczba postów: } 26\end{array}$} & \multicolumn{3}{|c|}{$\begin{array}{l}\text { LinkedIn } \\
\text { (0 postów } \\
\text { po polsku) }\end{array}$} \\
\hline $\begin{array}{l}\text { typ treści } \\
\text { wymiar różnorodności [\%] }\end{array}$ & $\begin{array}{c}\text { tekst } \\
100\end{array}$ & $\begin{array}{c}\text { grafika } \\
84\end{array}$ & $\begin{array}{c}\text { wideo } \\
13\end{array}$ & $\begin{array}{c}\text { tekst } \\
100\end{array}$ & $\begin{array}{c}\text { grafika } \\
100\end{array}$ & $\begin{array}{l}\text { wideo } \\
-\end{array}$ & tekst & $\begin{array}{c}\text { grafika } \\
-\end{array}$ & wideo \\
\hline poglądy polityczne [\%] & - & - & - & - & - & - & - & - & - \\
\hline $\begin{array}{l}\text { różnorodność jako wartość } \\
{[\%]}\end{array}$ & \multicolumn{3}{|c|}{-} & \multicolumn{3}{|c|}{-} & \multicolumn{3}{|c|}{ 一 } \\
\hline
\end{tabular}

Żaden z wymiarów nie pojawił się we wszystkich typach treści, na wszystkich badanych profilach. Bez rozróżnienia na typy treści we wszystkich kanałach firma nawiązywała do różnorodności pod względem wieku, płci, doświadczenia zawodowego i, najczęściej, stylu życia. W bieżącej komunikacji IKEA nie nawiązała do wymiarów: pochodzenia etnicznego, rasy, narodowości, wykształcenia, statusu rodzicielskiego, stanu majątkowego, miejsca pracy, systemu wartości, hobby, poglądów politycznych, nie zaprezentowała też różnorodności jako wartości.

\section{McDonald's}

Spośród uwzględnionych kanałów McDonald's korzysta z zakładki kariery na stronie internetowej ${ }^{46}$ (po polsku, angielsku, rosyjsku i ukraińsku), szablonu ogłoszenia w portalu Pracuj.pl oraz profilu na LinkedIn ${ }^{47}$ (w języku polskim). Profile w innych uwzględnionych social mediach (kliencki na Facebooku ${ }^{48}$, kliencki ${ }^{49}$ oraz rekrutacyjny ${ }^{50}$ na Instagramie) w okresie badania były nieaktywne. Firma nie miała także uzupełnionego profilu w portalu Pracuj.pl ${ }^{51}$ (zawierał jedynie ogłoszenia).

Najbardziej dosłowną deklarację postrzegania różnorodności jako wartości zawiera szablon ogłoszenia rekrutacyjnego: „Angażujemy się w tworzenie otwartego i integrującego środowiska pracy, w którym różnorodność zespołu jest jego wartością, a wszyscy pracownicy traktowani są z godnością i szacunkiem" ${ }^{52}$. Jednocześnie menadżerowie przyznają, że różnorodność może stanowić wyzwanie („Na pewno sporym wyzwaniem jest budowanie różnorodnego zespołu”53), choć

46 https://praca.mcdonalds.pl (dostęp: 31.12.2020).

47 https://www.linkedin.com/company/mcdonald's-polska (dostęp: 31.12.2020)

$48 \mathrm{https}: / /$ www.facebook.com/McDonaldsPolska (dostęp: 31.12.2020).

$49 \mathrm{https}: / /$ www.instagram.com/mamsmakanamaka/ (dostęp: 31.12.2020).

50 https://www.instagram.com/witamywmcdonalds/ (dostęp: 31.12.2020).

$51 \mathrm{https}: / /$ pracodawcy.pracuj.pl/mcdonalds-polska-sp-z-o-o,3510 (dostęp: 31.12.2020).

52 https://www.pracuj.pl/praca/it-risk-supervisor-specjalista-ds-standardow-i-bezpieczenstwa-it-warszawa,oferta,1000653967?s=c1cf5fc1 (dostęp: 31.12.2020).

53 https://praca.mcdonalds.pl/blog/post/pracowalam-w-roznych-miejscach-ale-dopiero-w-mcdonald-s-dostalam-szanse-na-rozwoj (dostęp: 31.12.2020). 
daje też wiele korzyści („Można się tu nauczyć tolerancji, dyscypliny, otwartości na ludzi, a nawet podszkolić języki obce, bo mamy kolegów i koleżanki z innych krajów" $" 54$ ).

Konkretne wymiary różnorodności wskazane są na przykład w opisie na niepolskojęzycznych wersjach strony kariery, między innymi: „The employees include students, seniors, the disabled, and young mothers who combine work with upbringing”, „Respect for everyone, regardless of where they come from”.

Na polskojęzycznej wersji strony firma zwraca uwagę na różnice doświadczenia zawodowego („Wracasz do życia zawodowego po dłuższej przerwie? A może nigdy nie pracowałeś/aś?"). Prezentuje też dane statystyczne między innymi o wieku pracowników („18 lat ma najmłodszy manager restauracji”, „49 lat ma najstarszy kierownik restauracji”). Na stronie znajdują się wypowiedzi pracowników. Wybrzmiewa w nich różnorodność w wymiarach: statusu rodzicielskiego - „McDonald's jest idealnym pracodawcą dla mam”, wykształcenia/systemu wartości — „nigdy nie muszę rezygnować z zajęć na uczelni. Studia są dla mnie priorytetem i kierownik restauracji rozumie to w stu procentach!”, wieku — „Jak się pracuje z młodymi? Ja sama czuję się przy nich młodo". Firma zwraca dużą uwagę na integrację zawodową osób starszych - co podkreśla między innymi jeden z menedżerów w wywiadzie na blogu stanowiącym część strony kariery: „Dojrzali pracownicy też świetnie się odnajdują w McDonald's i nieraz słyszałem, że ktoś czuje, że odmłodniał, pracując w tak różnorodnym zespole" ${ }^{\text {. }}$. Inna menadżerka zwraca uwagę na różnorodność narodowości, przywołuje pracę z osobami z Ukrainy, Indii i Maroka ${ }^{56}$. Na podstronie z ofertami pracy firma wymienia za to dokumenty rekrutacyjne, wśród nich między innymi dokumenty potwierdzające ,szczególne uprawnienia pracownicze, czyli np. orzeczenie o niepełnosprawności”"57.

Język w analizowanych tekstach jest zwykle neutralny płciowo, na przykład dzięki stosowaniu form pierwszej osoby liczby mnogiej czasu teraźniejszego (,staramy się dostosować do rozmaitych planów i sytuacji naszych pracowników" ${ }^{\text {"58) }}$ lub drugiej osoby liczby pojedynczej z alternatywnymi zakończeniami czasowników w czasie przeszłym („A może nigdy nie pracowałeś/aś?”59) — choć trafiają się przymiotniki w rodzaju męskim (,Jeśli Ty jesteś zadowolony, my również!’60).

54 https://praca.mcdonalds.pl/blog/post/wyjscie-do-pracy-to-przede-wszystkim-wyjscie-do-ludzi (dostęp: 31.12.2020).

55 https://praca.mcdonalds.pl/blog/post/praca-w-mcdonald-s-dostarcza-mi-wielu-powodow-do-dumy (dostęp: 31.12.2020).

56 https://praca.mcdonalds.pl/blog/post/pracowalam... (dostęp: 31.12.2020).

57 https://praca.mcdonalds.pl/oferty-pracy (dostęp: 31.12.2020).

58 https://praca.mcdonalds.pl/o-mcdonalds (dostęp: 31.12.2020).

59 https://praca.mcdonalds.pl (dostęp: 31.12.2020).

60 Ibidem. 
W analizowanych kanałach firma wykorzystywała przede wszystkim indywidualne zdjęcia pracowników i pracownic w różnym wieku, o różnym wyglądzie, na różnych stanowiskach — przy czym fotografii kobiet jest więcej. Grafiki nawiązują też do wymiarów: hobby, statusu rodzicielskiego, wykształcenia, wieku.

W okresie badania firma nie zamieszczała filmów w kanałach analizowanych jakościowo.

Podstawowe działanie, które warto podkreślić jako wspierające różnorodność, to dostosowanie strony kariery do potrzeb osób o różnym stopniu sprawności, przez dodanie przycisków do zmiany rozmiaru treści lub kontrastu oraz możliwość nawiązania wideopołączenia z tłumaczem języka migowego. Jak wspomniano, strona ma też cztery wersje językowe. Sama firma jako główne rozwiązanie wspierające różnorodność prezentuje elastyczność czasu pracy — odpowiada tym samym szczególnie na potrzeby matek ${ }^{61}$ i studentów $^{62}$.

Firma zapewnia, że ,możliwości rozwoju są takie same dla młodych osób, zaraz po szkole, jak i dla dojrzałych pracowników"63. To między innymi szkolenia wdrożeniowe, których koszt w całości ponosi firma ${ }^{64}$ (wykazując troskę o różnice stanu majątkowego). Firma nawiązała współpracę z Uniwersytetem Trzeciego Wieku ${ }^{65}$, by aktywizować zawodowo osoby starsze. W 2019 roku firma sfinansowała 60 pracownikom studia na kierunku zarządzanie w sektorze QSR (restauracji szybkiej obsługi) ${ }^{66}$, by rozwijać ich kwalifikacje i ułatwić przyszłą pracę na kierowniczych stanowiskach. Firma deklaruje równe traktowanie (umowa o pracę) i szanse rozwoju niezależnie od narodowości ${ }^{67}$.

Badanie jakościowe wykazało, że McDonald's w komunikacji employer brandingowej nawiązuje do jedenastu uwzględnionych wymiarów różnorodności. $\mathrm{Na}$ tej podstawie zostały opracowane kategorie do analizy metodą ilościową, której wyniki prezentuje tabela 4.

W okresie badania firma publikowała treści tylko na profilu LinkedIn. Płeć i wiek to jedyne wymiary różnorodności, do których nawiązano w każdym typie treści, choć wymiarem, który pojawił się w największym procencie wszystkich postów, jest niepełnosprawność. W bieżącej komunikacji nie pojawiły się nawiązania do języka, statusu rodzicielskiego, stanu majątkowego, wyglądu fizycznego, a różnorodność nie została przedstawiona jako wartość.

61 https://praca.mcdonalds.pl/blog/post/wyjscie-do-pracy-to-przede-wszystkim-wyjscie-do-ludzi (dostęp: 31.12.2020).

62 https://praca.mcdonalds.pl/o-mcdonalds (dostęp: 31.12.2020).

63 https://praca.mcdonalds.pl/blog/post/pracownicy-mcdonald-s-rozpoczeli-ii-rok-studiow-na-akademii-leona-kozminskiego (dostęp: 31.12.2020).

64 https://praca.mcdonalds.pl (dostęp: 31.12.2020).

$65 \mathrm{https} / /$ praca.mcdonalds.pl/blog/post/praca-w-mcdonald-s-dostarcza-mi-wielu-powodow-do-dumy (dostęp: 31.12.2020).

66 https://praca.mcdonalds.pl/blog/post/pracownicy... (dostęp: 31.12.2020).

${ }^{67} \mathrm{https}: / /$ praca.mcdonalds.pl/en (dostęp: 31.12.2020). 
Tabela 4. Wymiary różnorodności w komunikacji firmy McDonald's w social mediach (1.1031.12.2020)

\begin{tabular}{|c|c|c|c|c|c|c|c|c|c|}
\hline McDonald's & \multicolumn{3}{|c|}{$\begin{array}{c}\text { Facebook } \\
\text { (profil nieaktywny) }\end{array}$} & \multicolumn{3}{|c|}{$\begin{array}{c}\text { Instagram } \\
\text { (profil nieaktywny) }\end{array}$} & \multicolumn{3}{|c|}{$\begin{array}{c}\text { LinkedIn } \\
\text { liczba postów: } 29\end{array}$} \\
\hline $\begin{array}{l}\text { typ treści } \\
\text { wymiar różnorodności [\%] }\end{array}$ & tekst & $\begin{array}{c}\text { grafika } \\
-\end{array}$ & wideo & tekst & $\begin{array}{c}\text { grafika } \\
-\end{array}$ & wideo & $\begin{array}{c}\text { tekst } \\
100\end{array}$ & $\begin{array}{l}\text { grafika } \\
66\end{array}$ & $\begin{array}{l}\text { wideo } \\
34\end{array}$ \\
\hline wiek [\%] & - & - & - & - & - & - & 3 & 3 & 14 \\
\hline płeć [\%] & - & - & - & - & - & - & 10 & 7 & 3 \\
\hline niepełnosprawność [\%] & - & - & - & - & - & - & - & - & 21 \\
\hline język [\%] & - & - & - & - & - & - & - & - & - \\
\hline narodowość [\%] & - & - & - & - & - & - & - & - & 3 \\
\hline wykształcenie [\%] & - & - & - & - & - & - & 3 & 一 & - \\
\hline status rodzicielski [\%] & - & - & - & - & - & - & - & 一 & - \\
\hline stan majątkowy [\%] & - & - & - & - & - & - & - & - & - \\
\hline $\begin{array}{l}\text { doświadczenie zawodowe } \\
{[\%]}\end{array}$ & - & - & - & - & - & - & - & - & 14 \\
\hline hobby [\%] & - & - & - & - & - & - & 3 & - & - \\
\hline wygląd fizyczny [\%] & - & - & - & - & - & - & - & - & - \\
\hline $\begin{array}{l}\text { różnorodność jako wartość } \\
{[\%]}\end{array}$ & & - & & & - & & & - & \\
\hline
\end{tabular}

\section{PZU}

Spośród uwzględnionych kanałów PZU korzysta z zakładki kariery na stronie internetowej ${ }^{68}$, szablonu ogłoszenia w portalu Pracuj.pl oraz profili na Faceboo$\mathrm{ku}^{69}$, Instagramie ${ }^{70} \mathrm{i}$ LinkedIn $^{71}$. Kanały prowadzone są w języku polskim. Firma nie opracowała profilu pracodawcy na Pracuj.pl — zawiera on jedynie ogłoszenia.

W komunikacji w kanałach analizowanych jakościowo PZU nie odnosiło się do różnorodności jako wartości - firma właściwie nie stosuje tego pojęcia, nie licząc stwierdzeń na stronie kariery, w sekcji „Co możemy Ci zaoferować”: „Przyjazną atmosferę pracy, tworzoną przez różnorodnych członków zespołu” oraz „Stabilne zatrudnienie i różnorodne perspektywy rozwoju wewnątrz organizacji" ${ }^{72}$.

Podstawowy wymiar różnorodności w tekstach PZU to doświadczenie zawodowe (a częściowo - wykształcenie, w kontekście osób dopiero je zdobywają-

\footnotetext{
${ }^{68}$ https://www.pzu.pl/kariera (dostęp: 31.12.2020).

69 https://www.facebook.com/pzukariera/ (dostęp: 31.12.2020).

$70 \mathrm{https} / / / \mathrm{www}$. instagram.com/pzukariera/?hl=pl (dostęp: 31.12.2020).

$71 \mathrm{https}: / /$ www.linkedin.com/company/pzu/ (dostęp: 31.12.2020).

72 https://www.pzu.pl/kariera/poznaj-pzu/dlaczego-warto-z-nami-pracowac (dostęp: 31.12.2020).
} 
cych) — na stronie kariery i profilu LinkedIn znajdują się zakładki dla konkretnych grup kandydatów: profesjonalistów, studentów/absolwentów, ekspertów IT, pracowników Contact Center, agentów ubezpieczeniowych. Na podstronie dotyczącej pracy w Contact Center firma ogłasza, że szuka „ludzi o różnych doświadczeniach i zainteresowaniach", ,w różnym wieku czy stopniu sprawności" ${ }^{73}$. W tekstach na pozostałych podstronach firma nie nawiązuje do innych wymiarów, oprócz płci. Ten wymiar różnorodności pojawia się w dwóch opisach na podstronie dla ekspertów IT: „Regularnie dzielimy się swoją specjalistyczną wiedzą z koleżankami i kolegami” i „wybieramy Mistrzynię/Mistrza IT PZU”.

Język w analizowanych kanałach, ze względu na częste stosowanie formy drugiej osoby liczby mnogiej, jest raczej neutralny płciowo. Warto zwrócić uwagę na wspomniane feminatywy. W bezpośrednich zwrotach do czytelnika zdarzają się przymiotniki w rodzaju męskim (na przykład ,,jesteś doceniany i nagradzany" ${ }^{94}$ ).

W badanych kanałach PZU zamieszcza zdjęcia pracowników, ale często wykorzystuje grafiki - rysunki przedstawiające postaci w sytuacjach zawodowych. Przedstawiane są kobiety i mężczyźni, choć zdarza się, że w niektórych zakładkach widoczne są w większości lub tylko kobiety. Na zdjęciach przedstawione są osoby w podobnym wieku (między 30 a 40 lat), szczupłe, o białym kolorze skóry. W sekcji „Benefity” zdjęcia przedstawiają pracowników realizujących pasje sportowe.

Materiały wideo na stronie kariery, profilu LinkedIn i w szablonie ogłoszenia rekrutacyjnego są częścią kampanii employer brandingowej „Taka praca ma sens”. Zawierają krótkie wypowiedzi pracowników na temat tego, co nadaje sens ich pracy i co stanowi ich motywację. Film ma trzy wersje - „ogólną"75 oraz skupione na konkretnym obszarze: $\mathrm{IT}^{76}$ lub praca $\mathrm{w}$ oddziale ${ }^{77}$. W nagraniach występuja właściwie w równym stopniu kobiety i mężczyźni, w różnym wieku, o różnym wyglądzie fizycznym, mówiący o różnych pasjach i motywacjach (wymiar systemu wartości). Najczęściej stosowana jest wersja ogólna, która rozpoczyna się od słów jednego z pracowników: „Każdy z nas jest trochę inny. My, jako firma, jako marka, chcemy, by pozostał sobą, a jednocześnie mógł też rozwijać się dzięki nam”. Jednak wyrazy „różnorodność”, „różni” nie pojawiają się w materiałach.

Kampanię tę można uznać za działanie wspierające świadomość różnorodności (szczególnie punktów widzenia / systemu wartości). Takie znaczenie ma też element procesu rekrutacyjnego: kwestionariusz wskazujący, w jaki sposób kandydat najlepiej wykorzysta swój potencjał ${ }^{78}$. W ramach konkretnych rozwiązań wspie-

\footnotetext{
73 https://www.pzu.pl/kariera/obszary-pracy/contact-center (dostęp: 31.12.2020)

$74 \mathrm{https} / / / w w w . p z u . p l /$ kariera/poznaj-pzu/benefity (dostęp: 31.12.2020).

$75 \mathrm{https} / / /$ youtu.be/0OOyOe5zstc (dostęp: 31.12.2020).

76 https://youtu.be/N8HWeH_2A5Y (dostęp: 31.12.2020).

77 https://youtu.be/WHxNwkX0Wmw (dostęp: 31.12.2020).

78 https://www.pzu.pl/kariera/poznaj-pzu/proces-rekrutacji (dostęp: 31.12.2020).
} 
rających różnorodność PZU zapewnia szkolenia dostosowane do danego obszaru odpowiedzialności ${ }^{79}$, elastyczny czas pracy w Contact Center lub ,rozsądny czas pracy" w innych obszarach (by szanować czas prywatny). Do ,indywidualnych potrzeb" dopasowane są benefity ${ }^{80}$, co można traktować jako szacunek wobec różnorodnych stylów życia. Firma wspiera sportowe pasje pracowników - obecnie w czternastu dyscyplinach ${ }^{81}$. PZU angażuje się w działania dla studentów ${ }^{82}$, umożliwiając osobom wchodzącym na rynek pracy zdobycie pierwszych doświadczeń zawodowych.

Badanie jakościowe wykazało, że PZU w komunikacji employer brandingowej nawiązuje do różnorodności w dziewięciu uwzględnionych wymiarach — na tej podstawie zostały opracowane kategorie do analizy metodą ilościową, które wyniki prezentuje tabela 5 .

Tabela 5. Wymiary różnorodności w komunikacji firmy PZU w social mediach (1.10 31.12.2020)

\begin{tabular}{|l|r|c|c|c|c|c|c|c|c|}
\hline \multirow{2}{*}{ PZU } & \multicolumn{3}{|c|}{ Facebook } & \multicolumn{3}{c|}{ Instagram } & \multicolumn{3}{c|}{ LinkedIn } \\
& \multicolumn{2}{|c|}{ liczba postów: 39 } & \multicolumn{2}{c|}{ liczba postów: 36 } & \multicolumn{2}{c|}{ liczba postów: 49 } \\
\hline $\begin{array}{l}\text { typ treści } \\
\text { wymiar różnorodności [\%] }\end{array}$ & $\begin{array}{c}\text { tekst } \\
95\end{array}$ & $\begin{array}{c}\text { grafika } \\
82\end{array}$ & $\begin{array}{c}\text { wideo } \\
\text { tekst }\end{array}$ & $\begin{array}{c}\text { grafika } \\
100\end{array}$ & $\begin{array}{c}\text { wideo } \\
11\end{array}$ & $\begin{array}{c}\text { tekst } \\
100\end{array}$ & $\begin{array}{c}\text { grafika } \\
73\end{array}$ & $\begin{array}{c}\text { wideo } \\
33\end{array}$ \\
\hline wiek [\%] & - & 8 & 3 & - & 6 & - & - & 10 & 6 \\
\hline płeć [\%] & 5 & 18 & 5 & 8 & 8 & - & 14 & 18 & 10 \\
\hline niepełnosprawność [\%] & - & - & 3 & - & - & - & - & - & 2 \\
\hline wykształcenie [\%] & - & - & - & - & - & - & - & - & - \\
\hline $\begin{array}{l}\text { doświadczenie zawodowe } \\
\text { [\%] }\end{array}$ & 44 & - & - & 50 & - & - & 29 & - & - \\
\hline system wartości [\%] & 3 & - & 3 & 6 & - & 3 & - & - & - \\
\hline styl życia [\%] & - & - & - & - & - & - & - & - & - \\
\hline hobby [\%] & 23 & 23 & - & 22 & 22 & - & 18 & 18 & - \\
\hline wygląd fizyczny [\%] & - & 5 & 3 & - & 6 & - & - & 4 & 2 \\
\hline $\begin{array}{l}\text { różnorodność jako wartość } \\
\text { [\%] }\end{array}$ & & - & & & - & & & - & \\
\hline
\end{tabular}

Najczęściej przywoływanymi wymiarami były doświadczenie zawodowe i hobby, choć żaden z wymiarów nie pojawił się we wszystkich typach treści, we wszystkich kanałach. Bez rozróżnienia na typy treści we wszystkich kanałach firma nawiązywała do różnorodności wieku, płci, doświadczenia zawodowego,

\footnotetext{
79 https://www.pzu.pl/kariera/poznaj-pzu/rozwoj-w-grupie-pzu (dostęp: 31.12.2020).

80 https://www.pzu.pl/kariera/poznaj-pzu/dlaczego-warto-z-nami-pracowac (dostęp: 31.12.2020).

81 https:/www.pzu.pl/kariera/poznaj-pzu/benefity (dostęp: 31.12.2020).

82 https://www.pzu.pl/kariera/studenci (dostęp: 31.12.2020).
} 
hobby i wyglądu fizycznego. W bieżącej komunikacji firma nie nawiązała do wymiarów wykształcenia i stylu życia, nie zaprezentowała też różnorodności jako wartości.

\section{Bibliografia}

Gross-Gołacka E., Zarządzanie różnorodnością. W kierunku zróżnicowanych zasobów ludzkich w organizacjach, Warszawa 2018.

HRM Institute, Raport: Employer branding w Polsce 2020, Kraków 2020.

https://www.employear.com/pl/blog/wyszukiwarki-ofert-pracy.html.

http://odpowiedzialnybiznes.pl/karta-roznorodnosci/sygnatariusze-karty.

Kozłowski M., Employer branding. Budowanie wizerunku pracodawcy krok po kroku, Warszawa 2012.

Loden M., Rosener J.B., Workforce America! Managing Employee Diversity as a Vital Resource, Illinois 1991. 